\title{
GONDOLATOK AZ AGRÁRGAZDASÁG REGIONÁLIS FEJLESZTÉSI KONCEPCIÓJÁHOZ
}

(Some thoughts for the regional development concept of agriculture)

\section{DORGAI LÁSZLÓ}

A területi fejlődés egyenlőtlenségei Magyarországon is, mint bárhol a világon hosszú idó óta megfigyelhetök, és az is látszik, hogy a gazdasági fejlődéssel - vagy visszaeséssel - az ezzel járó problémák újratermelődnek. Ez a felismerés már a rendszerváltás elött is megfogalmazódott, a felismerés alapján az akkori kormányzat kezdeményezésére szuiletett országgyúlési határozat az „elmaradott”, „többszörösen hátrányos helyzetü” térségek „felzárkóztatását” tủzte ki célul, konkrét fejlesztési programok alapján. A programok azonban csak részben valósultak meg, hiszen szakmai megalapozottságuk is vitatható volt, a legnagyobb gondot azonban az jelentette, hogy hiányos volt a megvalósításukhoz szükséges eszközrendszer, leginkább a pénzủgyi háttér. A rendszerváltással együtt jelentkezó társadalmi-gazdasági változások a korábban is meglévő területi feszültségeket kiélezték, felszinre hoztak eddig nem tapasztalt feszültségeket is. Jellemző, hogy vidéken az ország társadalmi-gazdasági problémái ma is hatványozottan jelentkeznek és a problémák az agrárgazdaság állajpotához szorosan kapcsolódnak.

Megítélésünk szerint olyan társadalmi problémával állunk szemben, melynek következménye a vidék végleges leszakadása lehet, ami çsak társadalmi összefogással elkerülhető, és ehhez jelentős mennyiségủ fejlesztési forrás mozgósítása, illetve a meglévő források - kőztük az agrártárca keretében rendelkezésre álló támogatások - koordináltabb, célszerübb felhasználása is szükséges.

\section{A regionális agrárgazdasági célokat befolyásoló föbb tényezök}

A regionális agrárgazdasági célok megfogalmazásához számos körülmény - többek között az alábbiak - mélyreható mérlegelése szuikséges.

Az agrárgazdaság nemzetgazdasági szerepe

Kiemelendő, hogy a hazai, viszonylag olcsó élelmiszerellátás mellett mintegy 3 milliárd dolláros, más nemzetgazdasági ágazatokból nehezen előteremthető exportot teljesít, az exportteljesitménye növelhető.

A gazdasági folyamatok azonban évtizedünkben a mezőgazdaságnak sem kedveztek, hiszen a mezỏgazdaság által elóállított GDP 1990-tỏl négy év alatt 34\%-kal csökkent, 1990-ben az előző évhez képest 4,6\%-kal, 1991-ben 8,1\%-kal, 1992-ben 11,4\%-kal, 
1993-ban 14,7\%-kal. A csökkenő tendencia ugyan megállt, sőt 1994-ben az elöző évhez képest 1,5\%-os, 1995-ben 1\%-os növekedés volt megfigyelhető. A mezőgazdasági termelés visszaesése a nemzetgazdasági átlaghoz képest eröteljesebb volt, az 1994-től jelentkezö felemelkedés pedig szerényebb mértékủ. A mezőgazdaság részesedése a GDP-böl 1995-ben 6,4\% volt, kereken egyharmada a másfél évtizeddel korábbinak.

$A z$ utóbbi évek termeléscsökkenése kedvezötlen hatással volt nem csak a mezögazdaságból élök, hanem a mezőgazdasági részfoglalkozásúak jövedelem-viszonyaira is.

A termelés alakulásában az utóbbi két évben ugyan vannak biztató jelek, túlzott optimizmusra azonban nem ad okot, hogy az 1995. évi szarvasmarha-állomány csupán 56\%-a, a sertés 61\%-a, a juh 45\%-a, tyúkféle 57\%-a az 1986-1990 évek átlagának.

$\mathrm{Az}$ is látható, hogy az egyes régiól (mikrorégiók) szintjén a mezö- és erdőgazdálkodás nemzetgazdasági funkciói a régió adottságai és társadalmi igényei szerint megváltoznak, helyenként a termelési funkció háttérbe szorul vagy teljesen megszünik és tájvédelmi, természetvédelmi, vagy rekreációs szerepet kap. Az agrárgazdaságra különleges szerepet tölt be a kistelepüléseken és tanyákon, továbbá azokban a kistérségekben, ahol a népesség foglalkoztatása elsődlegesen a mezögazdaságra hárul.

\section{A termőföld bősége}

A termỏföld hazánkban bỏségesen rendelkezésre áll, akár az ország területéhez, akár a népesség számához viszonyitunk. Más természeti eröforrásokban viszont szegények vagyunk, éppen ezért a termöföld mennyiségének és minöségének megóvására különös gondot kell fordítunk. Arra törekszünk, hogy a mủvelésböl való kivonás (akár infrastruktúra, lakóterület, vagy más célra történik), a nem mezögazdasági célú hasznositás csak a legszükségesebb mértékủ legyen és a rosszabb minőségü földeket érintse.

A viszonylagos földböség azonban lehetóvé teszi, hogy:

- a termelést a piaci kereslet és más szempontok mérlegelésével bỏvíthessük;

- a termelésbővités során ne kényszerüljünk a termelés túlzott intenzifikálására, környezetterhelésre;

- a termelési szerkezetet és a termelés intenzitását is - közgazdasági szempontok érvényesitésével - a termỏhelyi adottságokhoz igazítsuk, a természeti adottságok, a termelési- és üzemstruktúra kedvező összhangját megteremtsük;

- a leggyengébb adottságú, ezért csak alacsony gazdasági hatékonyságú termelésre alkalmas, de ma még mezógazdasági hasznositású földterületeket az élelmiszertermelésből fokozatosan kivonjuk;

- megtaláljuk azokat a mikrorégiókat, melyek hagyományosan is egyedi jelleggel bíró, a piac által keresett specifikumok elöállítására alkalmas termóhelyek (föként gyümölcs- és zöldségfélék, szölö, gyógynövény, füszernövény), ezekre feldolgozókapacitások is alapozhatók.

\section{Kedvezö termelési és egyéb adottságaink}

A termeléshez kedvezó adottságokkal rendelkezünk (klimatikus viszonyok és földminőség, humán erőforrások mennyisége és minósége, termelési tapasztalatok, a mezőgazdálkodás terén tapasztalt vállalkozói készség, viszonylag fejlett termelöi infrastruktúra), ökológiai adottságaink lehetỏvé teszik, hogy az agrárgazdaságban a lényeges termelésbövités, a maihoz képest kétszeres, hảromszoros exportbővités valósuljon meg. Országunk centrális elhelyezkedése, távolságunk a hagyományos piacainktól a szállitási viszonyokban- és költségekben a versenytársakkal szemben elönyt jelent. Különösen nem 
elhanyagolható, hogy számos határainkon túli, de határainkhoz közel fekvő nagyváros helyi élelmiszertermelése a keresletet nem fedezi, így a határmenti kistérségek termelöi számára további potenciális piaci lehetöség jelentkezik.

\section{A természeti környezet állapota}

$\mathrm{Az}$ intenziv mezőgazdálkodást folytató országokhoz viszonyítva nálunk alacsonyabb a mezógazdasági termelésból eredô - a kemikáliák használata és a koncentrált területi elhelyezés miatt jelentkezõ - környezeti terhelés. Nem elhanyagolható viszont, hogy helyenként (nem nagy kiterjedésben, leginkább élővizek és üdülöővezetek mentén, természetvédelmi teruletek közelében) a termelés intenzitását környezetvédelmi megfontolásból csökkenteni kell.

\section{A mezốgazdaságban mũködố eszközök állapota}

A mezőgazdaság eszközállománya fizikai és erkölcsi értelemben is rendkívül elavult különösen az újonnan létrejött gazdaságokban.

$\mathrm{Az}$ állattartó telepek többsége negyed évszázaddal ezelött épült, a gépek átlagos életkora 9 év körül alakul. A mezőgazdaság vonóerö-kapacitása 1991-ben 7656 ezer kilowatt, 1995-ben 4632 kilowatt volt.

A foglalkoztatási és a vidéki népesség jövedelme szempontjából is rendkivül fontos ültetvények többségét még a hetvenes években telepítették, kor-, faj-, és fajtaösszetétele nagyon rossz és egyre romló. 1986 és 1990 között évi átlagban 1800 ha, 1991 és 1995 között már csak 500 ha gyümölcstelepités történt. A szölötelepittés mennyisége 19861990 közötti években átlagosan 2700 ha, 1991-1995 között csupán 200 ha volt. Ha tehát az ültetvénytelepítés az utóbbi ơt év átlaga szerint haladna, akkor a meglévő mintegy 225 ezer ha ültetvény megújitása 320 évet venne igénybe.

A mezőgazdaság esélye a müszaki-technikai megújulásra egyre rosszabb, hiszen a nemzetgazdaság összes beruházásaiból 1992-ben mindössze 1,6\%-kal, 1993-ban 1,4\%kal, 1994-ben 1,9\%-kal, 1995-ben 2,4\%-kal részesedett. Tanulságos szemügyre venni a mezỏgazdasági beruházások alakulását a mezőgazdaságnak a GDP-hez való hozzájárulása viszonyában is. 1980-ban a mezögazdaság a GDP-böl 18,6\%-kal, az összes beruházásból 12\%-kal, 1990-ben a GDP-ból 15,3\%-kal, a beruházásokból 6\%-kal, 1995-ben a GDP-böl 6,4\%-kal, a beruházásokból 2,4\%-kal részesedett.

\section{A mezõgazdasági termelés munkaerö-igénye, munkanélküliség, eltartóképesség}

Magyarország történetében az ötvenes évek erőltetett iparosítása, majd a mezögazdaság kollektivizálását követő müszaki fejlesztés közismerten nagyarányú munkaeröcsökkenést eredményezett a mezőgazdaságban. A rendszerváltást követően ugyancsak munkaerö-csökkenés jelentkezett, de egészen más okok következményeként és más volt a vidéki foglalkoztatásra gyakorol hatása is mint a korábbiaknak. A különbség egyrészt az, hogy az évtizedünkben tapasztalt csökkenés minden korábbinál drasztikusabb volt. Az 1986-1990 évek átlagában az aktiv keresök 17,9\%-át, 1991-1995 évek átlagában 11,2\%-át, 1995-ben viszont már csupán 8,5\%-át foglalkoztatta a mezögazdaság. A mezögazdasági aktiv keresōk aránya fél évtized alatt felére csökkent. Lényeges különbség továbbá az is, hogy a korábbi időszakokban más gazdasági ágak lekötötték a mezõgazdasági termelésből felszabadult munkaerōt, most viszont erre nem voltak képesek.

A munkanélküliség elöször 1989-ben jelent meg iparvállalatoknál, de hamar elérte a tipikusan mezőgazdasági jellegü térségeket is. A munkanélküliségi ráta (1996. február) 
országosan 11,6\%, az átlagot lényegesen meghaladó Szabolcs-Szatmár-Bereg $(21,2 \%)$, Borsod-Abaúj-Zemplén (18,7\%), Nógrád (18,3\%) és Hajdú-Bihar $(16,2 \%)$ megyékben. Az említett megyék falvaiban nem ritka a 40-60\%-os munkanélküliségi ráta.

A foglalkoztatási feszültségek a falvakban több okból eröteljesebben jelentkeznek. A korlátozottabb munkalehetöségek és az oktatási-szociális ellátás hiányosságai miatt a kistelepüléseken hagyományosan magas a munkaviszonnyal nem rendelkezỏ nők, következésképp az egykeresős családok aránya. Az is közismert, hogy az ipari munkáltatók ha volt választási lehetőségük - elöször az ingázó (vidékröl bejáró) dolgozóikat küldték el, ha létszámcsökkentésre kényszerültek. A városi, de vidéki telephelyekkel is rendelkezö vállalatok a kereslet csökkenése miatt elöbb a vidéki telephelyen folytatott termelést csökkentették, vagy szïntették meg. A vidéken jelentös, és korábban elsősorban keleti exportra termeló élelmiszeripar piacvesztése miatt jelentkezö termeléscsökkenés ugyancsak érzékenyen érintette a vidéki foglalkoztatottságot, nem csak közvetlenül, hanem közvetetten az alapanyag-elöállító mezögazdasági termelöket is. Mint láttuk, a mezögazdaságból is munkaerő szabadult fel, mert visszaesett a termelés, a korábbi nagyüzemek helyén gazdálkodó szervezetek és magángazdaságok egyébként is racionálisabb élömunka-felhasználásra törekednek, emellett jórésżt elsorvadtak azok a kiegészítö üzemágak is, melyek mezögazdasági szervezeti keretben, de nem mezőgazdasági tevékenységben foglalkoztattak dolgozókat. A mai vidéki állástalanok (regisztrált munkanélküliek és munkanélküli ellátásban nem részesullók, de munkahellyel sem rendelkezők) mintegy kétharmadát korábban mezögazdasági nagyüzemek foglalkoztatták.

A vidéki, falusi munkaerö-felesleg tartósnak ígérkezik, mert a mezőgazdasági termelés a mai szerkezet mellett még növekvő termékkibocsátással sem bövítheti jelentősen a foglalkoztatást. A termelési szerkezet tudatos formálásával, az integrációs kapcsolatok erősítésével, kiterjedtebb szolgáltató hálózattal, a feldolgozás bővítésével és nem utolsó sorban hatékonyabb marketing-tevékenységgel azonban a mostani foglalkoztatási szint stabilizálható, egyes mikrorégiókban növelhetö.

Kistelepüléseken az un. anyagi ágakban szinte kizárólag a mezö- és erdögazdálkodás kínál foglalkoztatási lehetőséget, és az is érzékelhető, hogy falvakban tartós igény jelentkezik a részmunkaidős fogialkoztatási formák iránt a nem agrárgazdaságban foglalkoztatottak körében is, továbbá a falusi töredék-munkaerö hasznosítására is

Különösen a nagy élömunka igényủ kultúrák fejlesztése kapcsán nem elhanyagolható komparatív elönyünk, nevezetesen, hogy nálunk az élömunka fajlagos költsége a nyugateurópai versenytársak költségéhez viszonyítva alacsony.

A népesség, a termelés és a terület eltartóképessége között számos kistérségben hoszszú idő óta ismert feszültségek léteznek. Például a Nyírségben és a Duna-Tisza-közi homokhátságon a más irányú foglalkoztatási lehetőségek hiánya miatt az agrárágazatra nehezedỏ túlzott foglalkoztatási igény tapasztalható. Helyenként - elsósorban ÉszakMagyarország és a Dunántúl aprófalvaiban - a népesség elöregedésével kapcsolatos gondok a legsúlyosabbak, hiszen törvényszerú, hogy a lemaradó térségekböl mindig felerösödik a fiatal és képzettebb néprétegek elvándorlása, a migráció idővel öngerjesztôvé válik, egyre romló korstruktúrát (elöregedést) és képzettségi-struktúrát eredményezve és ez a folyamat csak nagy áldozatok árán visszaforditható.

\section{Meglévö élelmiszer-feldolgozó kapacitásaink és elhelyezkedésük}

A gazdaságilag fejlett és mezógazdasági terméket exportáló országokban igen határozott törekvés, hogy ne alapanyagot, hanem feldolgozott terméket exportáljanak, a hazai termékkínálatban is a konyhakész termékek arányát növeljék. Ezt a logikát nekünk is 
célszerü követni. Magyarországon a mezőgazdasági alapanyagok feldolgozásra rendelkezésre álló kapacitások a mainál nagyobb volumenü alapanyag-termelésre méretezettek. A kapacitások térbeli elhelyezkedése - tehát az alapanyag-termelés és feldolgozás összhangja - korántsem ideális és az igényes piacok követelményéhez mérten a feldolgozók és termékeik korszerủsége is változó. Ma már az élelmiszer-feldolgozók döntően (80\%-ban) magántulajdonban vannak, a mezőgazdasági alapanyagokat feldolgozó iparágak elhelyezkedését, kapacitását csak közvetett úton, leginkább az alapanyag-kínálaton keresztül tudjuk befolyásolni.

\section{Belföldi élelmiszerkereslet}

Agrárgazdaságunk az utóbbi évtizedben a legnagyobb piacvesztést a belföldi fizetõképes kereslet visszaesése miatt szenvedte. Arra számíthatunk, hogy az életszínvonal javulása már rövid távon is az élelmiszerek iránti kereslet-élénküléssel jár. A jövedelmek differenciálódása pedig a fogyasztói igényekben az eddigieknél is markánsabban megjelenik.

\section{A termelés és települések kapcsolata}

A mezőgazdasági termelés és a települések kapcsolatára Magyarországon hagyományosan jellemzó volt, hogy a vidéki telepulések lakóterületként és a termelés tereként egyaránt funkcionáltak, különösen az állattartás és a hozzá szorosan kapcsolódó takarmánytároláson keresztül. Az Alföldön sajátos agrár-települések, tanyák alakultak ki. A nagyüzemi gazdálkodás általánossá válásával a települések és a termelés közötti korábbi szerves kapcsolat megbomlott, a termelö tevékenység súlypontja áthelyeződött a településeken kívül létrehozott nagyüzemi telepekre. A települések belterületén a mezőgazdasági tevékenység visszaszorult, nem érvényesült tudatos falufejlesztés, a tanyák jelentỏs része elsorvadt, vagy pedig korábbi szerkezetük lényegesen megváltozott. A tulajdon- és üzemstruktúra megváltozása következtében az eddigi, elsősorban a nagyiuzemi gazdálkodás és integrációs kapcsolatai szerint létrehozott termelési kapacitások (állattartó telepek, szárító és tároló kapacitások) területi elhelyezkedése ezért csak részben megfelelö, az új (közepes és kisméretú) termelö-, feldolgozó-, és szolgáltató vállalkozások területi elhelyezésére azonban a lakóterületek mostani kisméretư portái több szempontból csak korlátozottan alkalmasak, vagy egyáltalán nem alkalmasak.

\section{A termelés szolgáltató- és ellátó háttere}

A mezỏ- és erdőgazdasági termelés szolgáltató-ellátó háttere nagyon hiảnyos, lassan fejlődő, a gerincét képezö mezőgép ipar és annak ellátó hálózata mintegy évtizede szinte elsorvadt. A korábbi, alapvetöen nagyüzemekre épüló integrációs kapcsolatok - melyek sok esetben az eszközellátásra és szaktanácsadásra is kiterjedtek - is meglazultak, vagy megszűntek, új integrációk nehézkesen szerveződnek. Az agrár szellemi központok kisugárzó hatása az új gazdálkodóknál ma még nem kellően érvényesül. Arra számítunk, hogy a mainál lényegesen fejlettebb, a termelői igényeket kielégítỏ szolgáltató-ellátó hátteret a nyereséges mezőgazdasági termelés keresleti piaca hívja életre, az életképes kezdeményezések állami támogatásával. 


\section{Az agrárgazdaság mai térszerkezete}

Az agrárgazdaság mai térszerkezete - bár hangsúlyozandó, hogy a földhasználatban, a termelési struktúra alakításában, üzemméretben általában nem érvényesültek kellỏen a termóhelyi adottságok - nem minősithetổ egyetemlegesen. Például az Alfóld és a Dunántúl jobb adottságú régióiban az adottságokhoz igazodó takarmánytermelésre alapozott sertés-, baromfi-, szarvasmarha ágazatok egymásraépülése alapvetó feszültséget nem hordoz. Ugyanakkor városellátó övezetek csak részben alakultak ki (esetenként a korábbiak is elsorvadtak), így például a fơváros tejellátását Szolnok és Székesfehérvár térsége biztosítja. A zöldség- és gyủmölcsforgalmazásban a fóvárosi nagybani piac viszont túlzott szerepet kapott. A Duna-Tisza közén. az Alfold észak-keleti részén mindig is jelentős, a helyi foglalkoztatásban és gazdasági bázisban különösen fontos ültetvényes gazdálkodás ugyan ma is létezik, de az ültetvények kor-, faj-, és fajta szerinti megoszlása nem megfelelö. Általánosan jellemző, hogy a tájjellegú termelés háttérbe szorult.

\section{Nemzetközi integrációs törekvéseink és tapasztalatai}

Közismert, hogy a magyar agrárgazdaság fejlődésére a szocializmus idószakában nemzetkőzi integrációs kapcsolataink jelentős hatással voltak, hiszen az élelmiszergazdasági export több mint kétharmada a KGST keretében realizálódott. A rendszerváltás után ezeknek a piacoknak a nagy részéról ugyan kiszorultunk, de számos jel szerint $a$ korábbi piacok jó része visszaszerezhetō.

Ưj integrációs törekvéseinkkel kapcsolatban pedig az mérlegelendő, hogy az agrárgazdaság, de kúlönősen a földhasználat az EU talán legszigorúbban szabályozott terủlete. A termelés közvetlen támogatása - nemzetközi kötelezettség-vállalások miatt azonban egyre inkább háttérbe szorul, erősődik viszont az a tendencia, hogy sorsát a vidékfejlesztés részeként kezeljék és ennek megfelelően közvetett úton támogassák is.

$\mathrm{Az}$ EU költségvetésében a regionális problémák megoldása prioritást élvez, hiszen az erre is szolgáló strukturális alapok aránya a közösségi költségvetésben növekvỏ, ma hozzávetỏleg egyharmad arányt képviselnek. Az alapok felhasználási céljai az arányosabb területi fejlesztést, az elmaradottabb régiók felemelkedését szolgálják azáltal, hogy forrást teremtenek a gazdasági szerkezetváltásra-szerkezet átalakításra, a tartós munkanélküliség csőkkentésére, a mezőgazdaság korszerüsítésére és szerkezetének átalakítására és a rurális területek kőzvetlen támogatására. Az EU az 1995. decemberi mađridi csúcsértekezleten úgy döntött, hogy javasolja a tărsult országoknak (a csatlakozást megelózó modernizációs program keretében) az EU által pénzügyileg is támogatandó mezögazdasági és vidékfejlesztési strukturális program kidolgozását és megvalósítását.

\section{Milyen típusú mezőgazdaságot akarunk}

A mezőgazdaság kialakult szerkezete győkeresen csak nagy tőkebefektetés árán volna megvalósítható, ehhez nem rendelkezúnk forrásokkal. Az új szerkezet ismét tartósan megmerevíti a gazdálkodást, ezért is kủlönösen fontos tisztázni, hogy hosszabb távon milyen típusú mezógazdaságot akarunk. A termelési tényezők súlya és az agrárgazdaság társadalmi szerepe térben is változó, igy az uniformizáltság elkerülése alapvető érdekünk. Az egyes térségek eltéró adottságait mérlegelve, a létező területi feszültségek oldásának igényével is a különbözó adottságokhoz, különbözó típusú mezógazdasággal kell terveznünk. 
Versenyzö, profitorientált mezôgazdaság

Célszerü, hogy profitorientált mezőgazdaság müködjön az átlagosnál kedvezőbb adottságú területeken, ahol a termelők számos ágazatban az intenzív gazdálkodás és nagyméretben való termelés elỏnyeit is hasznosíthatják. Ilyen területek megtalálhatók mezorégiók szintjén, továbbá mikrorégiók szintjén a kedvezôtlen adottságú mezorégiókon belül, sỏt a kifejezetten rossz adottságú mikrorégiók, vagy települések kisebb határrészein is, ahol gyakran éppen a nagy élómunka igényủ ágazatok - így például ültetvények, zöldségfélék - versenyképesek. A versenyző, piacorientált típusú mezőgazdaság azokra a régiókra (körzetekre) koncentrálódik, ahol a szántó aranykorona értéke egy hektárra vetítve 19 folött van. Ilyen kistérségek nagyobb összefüggỏ egységekben az Alfơld tiszántúli részén a Hajdúságban, a Békési lőszháton, a Duna-Tisza kőzén a Duna vonalában; a Dunántúlon a Mezőfỏldön és a Kisalfơldön találhatók.

\section{Különleges termóhelyeken folytatott termelés}

Azokra a termőhelyekre gondolunk, ahol a talaj-, és klimatikus adottságok, egyéb természeti tényezők, továbbá a termelési hagyományok szerencsés kombinációja egyedi értékkel biró, a hazai- és exportpiacainkon is keresett termékek előállítását teszik lehetővé. Ide sorolhatók a borvidékek, bortermő helyek, a hagyományos gyümölcs- és zöldségtermelő vidékeink. Az itt előállított termékeknél rendkívül fontos a szigorú eredetvédelem garantálása. Említésre érdemes, hogy az ültetvények (szỏlö és gyümölcs) ökológiai adottságokhoz igazodó térbeni-területi elhelyezését megkönnyíti, hogy a termöhelyek kataszterszerü felmérése országosan elkészuilt, de zöldségféléknél is rendelkezünk megfeleló szakmai háttérrel megalapozott javaslatokkal.

\section{Extenziv mezőgazdálkodás a marginális területek hasznosítására}

Extenzív gazdálkodás olyan területeken tervezhetó, ahol a mai ráfordításhozamviszonyok mellett a termelés állami támogatás nélkül ugyan nem nyújt elegendő jövedelmet a gazdálkodók számára, de szerény mértékü, jövedelem-kiegészitỏ jellegü támogatással extenziv, alacsony eszközigényú és környezetbarát termelés fenntartható. Ezek a termőfỏldek egyben a termelésbővítés tartalékaiként is szolgálnak a mainál kedvezóbb piaci viszonyok esetére, hiszen a meglévő termelő kapacitások intenzívebb hasznositásával a termékkibocsátásuk növelhetö. Az extenzív mezőgazdaság a 17-19, kisebb részben pedig a 10-17 szántó-aranykorona minőségú területeken folytatandó.

\section{Foglalkoztatást javító, szociális típusú mezõgazdaság.}

Azokon a területeken szükséges tervezni, ahol a termelés fenntartása közgazdasági szempontból esetleg nem, de egyéb társadalompolitikai megfontolások alapján - más foglalkoztatási lehetöségek hiján - indokolható. Abból indulunk ki, hogy a tartós munkanélküliség vállalásának anyagi terhe és morális kára nagyobb annál, mint a célirányosan támogatott mezỏgazdálkodás fenntartása jelent. A szociális típusú mezőgazdaság területei

- a mikrorégiók tartós munkanélküliséggel sújtott falvai;

- a túlnyomóan cigány etnikumú népesség által lakott falvak (tapasztalataini zerint ezeknek a települések a zöme a tartós munkanélküliség által sújtott településcsoportba tartozik, koncentrált elhelyezkedésük Észak- és Kelet-Magyarországon leginkább jellemző). 
Különösen fontosnak tartjuk, hogy az effajta mezőgazdaságban elsődlegesen a munkaigényes, de kis eszközigényü, piacképes, semmiképpen nem tömegméretú terméket elóállitó ágazatok kapjanak helyet. A programszerủ kidolgozásában a már beindult szociális földprogram tapasztalatai is hasznosíthatók.

Családi szükségletre termelö, helyi ellátást javító mezögazdaság

Városoktól távol esỏ kistelepüléseken (mindenekelött Észak-Magyarországon és Dunántúlon) és tanyákon (Alföldön) az ellátási fogyatékosságok, de a kialakult szokások miatt is hosszú távon fennmarad olyan inezögazdaság, mely elsösorban a család és a szükebb lakókörnyezcte szükségletére termel, egyben hasznositva a töredék munkaeröt is.

\section{Visszavonuló mezőgazdaság}

Mintegy 700 ezer ha területen annyira gyenge a termöföld minösége, hogy a mezögazdasági termelés a mainál lényegesen kedvezöbb közgazdasági viszonyok mellet is csak nagyarányú állami támogatással lenne fenntartható, ezért a leggyengébb terïleteken a mezögazdálkodás fokozatos visszavonulásával és végső soron a szóban forgó területek erdősítésével, átmenetileg pedig extenzív gyepként való hasznosításával indokolt számolnunk. Az erdősítésre szánt területek gyakorlatilag minden mikrorégióban megtalálhatók.

A termelés visszavonulásának ütemét alapvetöen teherbíró képességünk meghatározza, hiszen a termőföld élelmiszertermelésböl való kivonása rövid távon nagyobb gazda- . sági terhet jelent, mint a támogatott termelés megtartása. Mérlegelendỏ továbbá az is, hogy az EU hajlandó-e az ez irányú törekvéseinket (a struktúraváltás keretében) már a csatlakozást elökészitó fázisban is támogatni.

Az erdőtelepítéssel kapcsolatos elöjelek nem kedvezőek, hiszen a hosszú távú telepítési célelöirányzat időarányosan nem teljesült.

Környezetvédelmi, tájvédelmi funkciót ellátó mezổgazdaság.

Kijelölt természetvédelmi területek és nemzeti parkok területein korlátozott (semmiképpen nem árutermelö célú), értékmegőrzó (többek között öshonos gazdasági állatfajok példányait megörzó) mezógazdálkodással számolunk. Hasonló funkciót szánunk a mezógazdaságnak azokon a területeken, ahol a talajvédelem, árvíz elleni védelem az elsődleges szempont.

A vázoltak szerinti mezőgazdálkodás kialakítása csak hatékony ösztönzéssel, támogatással lehet megvalósítható. Ehhez az agrártárca eszközei nerm elegendőek, különösen ha azt is fontosnak tartjuk, hogy a gyengébb adottságú területeken a struktúraváltás úgy valósuljon meg, hogy a jobb adottságú területektöl fejlesztési forrást ne vonjunk el.

\section{Vázlatosan a fontosabb regionális agrárgazdasági célokról}

Az agrárgazdaság regionális céljainak részletes kifejtésére terjedelmi korlátok miatt nincs lehetőségünk, csupán felsorolás-szerüen ismertetjük. 


\section{Mezógazdaság}

- Az Alfóldön a Dél-Alföld, a Hajdúság elsôsorban abraktermelés és abrakfogyasztó ágazatok (sertés, baromfi) régiója; a gyengébb területeken (Hortobágy, homokterületek) juhászat, a hagyományos ültetvényes kistérségekben (Nyírség, Duna-Tisza köze) az ültetvények korszerủsítve fennmaradnak;

- Észak-Magyarország gyepterületein a húsmarha- és a juh ágazat, borvidékein (tokaji, egri, mátrai) a minőségi szőloótermelés és borászat fejlesztendő;

- Dél-Dunántúl hagyományosan is szarvasmarha- és baromfitenyésztö övezet; a borvidékein (mecsek-villányi) szőlö-bor ágazattal;

- Észak-Dunántúl állattenyésztési föirányú, tej-hús szakosodással;

- A budapesti agglomeráció városellátó övezet-jellege (különösen zöldség-, és gyümölcstermelés) erősödik;

- Tógazdasági haltermelés az Alföld és Dunántúl meglévő tófelületein, müszakitechnológiai rekonstrukcióval.

\section{Erdő és vadgazdálkodás}

- Erdőtelepítések a célprogram elöirányzatai szerint, a telepítések mennyisége régiónként változó;

- Az erdők 80-85\%-a gazdasági célú marad, a véderdőknek kulönösen fontos szerepet tulajdonítunk a fokozott környezetterhelésnek kitett területeken;

- A vadgazdálkodásban az elönyös adottságainkat hasznosítjuk; a vadgazdálkodás, a mezö- és erdőgazdálkodás érdekeit összhangba hozzuk.

\section{Élelmiszeripar}

- A mezőgazdasági termékek elsódleges feldolgozására épüló iparágaknál (húsipar, baromfifeldolgozó ipar, takarmánygyártás, tejipar, boripar) az alapanyag-termelés és feldolgozó-kapacitások ősszehangolása minden régióban alapvető érdekünk;

- A kis- és középvállalkozásokat az eredeti, táji jellegü, a vegyszer mentes (bio) termék-elöállítás terén, továbbá vállalkozási övezetekben és innovációs centrumokban célszerü ösztönözni.

\section{Agrárgazdasági célok térségtipusok szerint:}

Az agrárgazdaság alapvetỏ problémái, nehézségei - a termelök tőkeszegénysége, a termelésben alacsony ráfordítási színvonal, erösen elavult eszközállomány, a mezógazdasági termelés- és foglalkoztatottság visszaesése, nem megfelelö földhasználat, az új gazdálkodók tapasztalatlansága - az összes problémás térségtỉpusban (mezỏgazdasági vidékfejlesztés, gazdaságilag elmaradott, ipari válság, tartós munkanélküliséggel sújtott) fellelhetők. Az emlitett térségek további leszakadásának megállitásában, majd fejlesztésében az agrárgazdaság szerepvállalása számottevó lehet:

- A foglalkoztatási viszonyok javitásával (különösen a tartós munkanélküliséggel sújtott kistérségekben);

- A gazdasági bázis növelésén keresztül (alapanyag-termelés és élelmiszeripar);

- A népesség helybenntartásával (falvakban és tanyákon). 
Az agrárgazdasági célok megvalósításának eszközrendszere

Az agrártárca keretében rendelkezésre álló pénzủgyi eszközök ma részben általános agrárgazdasági (struktúraváltás, múszaki fejlesztés-modernizáció, a termékek piacra jutásának segítése), részben speciális célokat szolgálnak. A speciális célok között a kedvezótlen adottságok között termelö gazdálkodók számára a jövedelem-kiegészító jellegú támogatást (mủvelési ágtól és a fỏld minóségétől fủggően, differenciáltan) fenn kell tartani, csakúgy mint à befektetésekhez nyújtott többlet támogatást, továbbá a telepítés helye és fafajok szerint differenciált erdósítési támogatást is. A támogatási rendszer fokozatosan úgy módosítandó, hogy az országos célkitüzésekkel összehangolt térségi (kistérségi) programok keretében kitüzött célok megvalósítására ösztönözzön, ugyanakkor lehetővé tegye az EU strukturális alapokkal való kapcsolódást, illeszkedést is.

A siker érdekében arra kell törekedni, hogy az agrártárca keretében rendelkezésre álló források mellett az agrárgazdasági célok megvalósításába a más tárcáknál rendelkezésre álló forrásokat, kiegészitő támogatásként bevonjuk, az agrártámogatásokat az említett források felhasználásával - kiemelten a területfejlesztési célelóirányzat, a munkaerőpiaci alap felhasználásával - összehangoljuk. Ennek az elvnek az érvényesítését azért tartjuk fontosnak, mert az agrárgazdaság minden beavatkozási térségtípusban közvetlenül vagy közvetetten érintett.

\section{Mezôgazdaság-és vidékfejlesztés}

A „vidékfejlesztés” önállóan használt kifejezésként ma még nem elterjedt Magyarországon, nem úgy, mint azokban a szervezetekben, integrációkban (OECD, EU) ahová hazánk - szándéka szerint - illeszkedni kíván. A vidékfejlesztés, mint társadalmi célkitũzés, az említett szervezetekben egyre nagyobb szerepet kap, e kérdéskörrel az OECDben évek óta ónálló munkacsoport foglalkozik’, az Európa Tanács 1995-ben dokumentumot tárgyalt a vidékfejlesztésról ${ }^{2}$, továbbá az EU-nak a hozzánk intézett, a tagfelvételt előkészítő kérdései kőzött a mezőgazdasággal kapcsolatban külön is megjelent a vidékfejlesztés ${ }^{3}$. A vidék problémája iránt a mai magyar társadalom is érzékeny és fogékony és kedvezó az is, hogy a gazdaságilag fejlett országok tapasztalatait egyre szélesebb körben megismerjưk és megismertetjuk.

Az OECD országok határozott tơrekvése tőbbek kőzőtt, hogy vidékfejlesztési programokkal a népesség számára a vidéki életmód és lakóhely választásának esélyét fenntartsák, a vidéki lakosságnak a nemzeti színvonalhoz hasonló életszínvonalat nyújtsanak, a vidék természeti és kulturális ơrökségeit megóvják. Magyarország formálisan is felvállalta ezeket az elveket, hiszen 1996-ban tagja lett az OECD-nek.

A rurális (vidéki) térségek megkưlönbőztetett kezelése hazánkban tőbbek között azért indokolt, mert:

- az ország terulletének mintegy 83\%-a az OECD-ben alkalmazott minösítés elve alapján rurális térség;

- a fejlesztési források elosztásakor hosszú időn át háttérbe szorultak, a kőzelmúlt társadalmi-gazdasági átalakulásának legnagyobb vesztesei;

- gazdasági teljesítőképességùk, népesség-eltartó képességúk gyengébb, sérülékenyebb, a kialakult gazdasági struktúra megváltoztatása nehézkesebb; 
- a helyi népesség megélhetésében nagy szerepe van a megújuló természeti erőforrásokkal való gazdálkodásnak (mezőgazdaság, erdő- és vadgazdálkodás, halászat);

- a befektetők (befektetések) számára elönyként szinte csak az olcsóbb munkaeröt kínálják, ezzel azonban nem képesek ellensúlyozni a más vonatkozásban jelentkező (például: infrastruktúra fogyatékosságai, periférikus fekvés) hátrányokat;

- a népesség helyben történö foglalkoztatásának lehetőségei korlátozottak, a hagyományos vidéki nemzetgazdasági ágazatok (mezőgazdaság, erdőgazdálkodás, bányászat, kézmúipar) munkaeröigénye csökkenö;

- nemzeti és természeti értékek kulcsfontosságụ elemeit hordozzák és védik;

- az urbánus térségekben, városokban élök számára rekreációs lehetöséget kínálnak.

Tekintve, hogy a mezö- és erdőgazdálkodás a vidékhez szervesen kötődik, a vidékfejlesztési stratégia kidolgozását és a megvalósitás eszközrendszerének koordinálását - a gazdaságilag fejlett országok gyakorlatához hasonlóan - az agrártárca feladatává célszerủ tenni. Fontosnak tarjuk azt is, hogy a vidékfejlesztés az országos területfejlesztési koncepcióban prioritásként szerepeljen.

A mezőgazdaság szempontjából a vidékfejlesztés általónos követelményei:

- a népesség számára a vidéki életmód- és lakóhely választási lehetőségének megtartása;

- a vidéken élók életszínvonalának javitása, pénzintézeti és egyéb szolgáltatások fejlesztése;

- falufejlesztés, falumegújitás, tanyák életképességének javítása;

- a falun élök számára a foglalkoztatási lehetöségek javítása (a tevékenységi kör diverzifikálása, integrációk fejlesztése, a falusi turizmus feltételeinek javítása);

- a természeti értékek, a föld és az élö környezet fokozott védelme, környezetbarát technológiák elterjesztése, a használat során sérült tájak rekultiválása;

- a fenntartható mezỏgazdálkodás és erdógazdálkodás feltételeinek megteremtése, a termelés modernizálása, hatékonyabb birtokstruktúra kialakítása;

- a földhasználati struktúra megváltoztatása, az adottságokhoz jobban igazodó termelési struktúra kialakitása, a leggyengébb adottságú területeken a föld nem termelési célú hasznosításának segítése.

A vidékfejlesztés pénzügyi eszközrendszerét és annak müködtetését $a z E U$ rendszeréhez hasonlóan szükséges kialakítani, összhangot teremtve az agrártámogatási rendszerrel is.

\section{Jegyzetek}

I Rural Development Group.

2 European Charter for Rural Areas. Council of Europe. Strasbourg, 29 January 1996.

3 EU kérdöívek ,2. Mezögazdaság III. Vidékfejlesztési politika”.

\section{Irodalom}

Dorgai L.-Hałász P.-Tóth E. (1988) Fejlesztési esélyek és irányok a gazdaságilag elmaradott térségekben. AKI tanulmány, Budapest.

Fazekas B. (1994) A hátrányos helyzetủ mezőgazdasági térségek. Statisztikai Szemle, I.

Fehér A. (1993) Vảiság-fơlahasználat-megélhetés az észak-magyarországi elmaradoft agrártérségekben. Gazdálkodás, I0.

Fehér A. (1995) Agrárpolitikai megoldások a regionális feszültségek kezelésére. A Falu, 3. 
Kukovics S. (szerk.) (1972) Kedvezötlen természeti adottságú mezőgazdasági területeink. Akadémiai Kiadó, Budapest.

Mészáros S. - Spitálszky M.(1996) Exportképességunnk várható változásainak vizsgálata az EU-csatlakozásig terjedổ idöszakban. AKIl tanulmány, Budapest.

Tanka E. - Spitálszky M. - Szúcs I. (1995) A kínálat szabályozás két eszkơze (fơldpihentetés és termelési kvóták). AKII tanulmány, Budapest.

Tóth E. - Varga Gy. (199I) A mezőgazdasági termelöszövetkezetek helyzete és sorsa az átalakulás idöszakában. AKII tanulmány, Budapest.

Udovecz G. (témavezető) (1995) Költség- és jövedelemarányok az átalakuló agrárgazdaság föbb termékpályăin. AKII tanulmány, Budapest.

\title{
SOME THOUGHTS FOR THE REGIONAL DEVELOPMENT CONCEPT OF AGRICULTURE
}

\author{
LÁSZLÓ DORGAI
}

The Parliament passed the Act on Regional Development and Physical Planning in the spring of 1996, with the purpose to support a regional development more proportionate than the previous ones in Hungary. A regional development concept for Hungary is prepared based on the Act, containing the concepts of the specific branches of the economy. This short essay gives some thoughts for the creation of the concept of the agriculture. It takes the factors and conditions to be evaluated during the creation of the concept into consideration: large agricultural areas, favourable endowments for production, state of the natural environment, the role of agriculture in the economic life of Hungary, the geographical location of Hungary, the situation of employment, unemployment, the state of the agricultural machinery, the connection of production and the settlements, and the present spatial structure of agriculture. It outlines the changes necessary in the land use, coming from the different endowments and conditions: profitoriented agriculture in areas with favourable endowments, in areas with special endowments production of specific products, extensive agriculture for the utilisation of marginal areas, a social type agriculture in micro regions struck by unemployment, agriculture producing for family needs in areas badly provided with retail shops, withdrawing agriculture in lands with the worst quality. It shows regional sectoral objectives of the agriculture, forestry and food processing industry. As agriculture has a strong and organic connection with rural areas, the essay examines the development of the agriculture as part of the logical system of rural development.

Translated by Zoltán Raffay 